\title{
Exploring the Relationship among Offenders, Victims and Bystanders of Violence: Analysis of Herdsmen Victimization in Nigeria
}

\author{
Michael Christopher Eraye, Chinwokwu Eke Chijioke* \\ Department of Sociology, Federal University of Lafia, Nasarawa State, Nigeria
}

Received October7, 2019; Revised November 19, 2019; Accepted November 25, 2019

Copyright $\mathrm{O} 2020$ by authors, all rights reserved. Authors agree that this article remains permanently open access under the terms of the Creative Commons Attribution License 4.0 International License

\begin{abstract}
This study explored the prevalence of violence orchestrated by herdsmen in Nigeria, with a view to situating the nature of the relationship that exists among the herdsmen, residents and bystanders which triggers further violence. The paper acknowledges that, violence perpetrated by herdsmen has reached an alarming proportion and the government has not marshaled enough political will to address the problem because of the apathy shown towards checkmating the menace. By way of qualitative analysis of secondary sources, the paper posited that violence spearheaded by herdsmen was directly and indirectly encouraged by government and security agents to victimize the vulnerable population by them in actions and body language of government. The paper further observed that violence was exacerbated by the nature of the relationship that exists among the herders, residents and those saddled with constitutional responsibility to protect the residents. The relationship among the herdsmen, victims and bystanders has negative implications on arrest and prosecution of the criminal herdsmen whose activities have jeopardized the futures of many Nigerians. The paper recommended among others that government should hold unto its constitutional responsibility of providing security for all Nigerians, irrespective of ethnic and religious affiliation and community leaders must ensure that indiscriminate and unregulated accommodation of herdsmen in their communities is checkmated. Government should take decisive action by proscribing Miyetti Allah under whose umbrella herdsmen perform their heinous crimes.
\end{abstract}

Keywords Offenders, Bystanders, Victims, Bystander of Violence, Victimization

\section{Introduction}

Nigeria is a creation of the colonial masters. It was in 1914 that the then colonial (British) representative Lord Frederick Lugard joined the North and Sourthern protectorates in an unconsented matrimony that have remained the undoing of Nigeria as a country. Before, 1914 the people living in the geographical entity called Nigeria had separate political and economic structures. Nigeria is a multilingual and multiethnic nation with over 400 ethnic groups (Badejo, 1989). The Hausa/Fulani, Igbo and Yoruba are the main ethnic groups in Nigeria while Christianity and Islam are the major religions in the country. The Hausa/Fulani dominates the North, Igbo in the East and Yoruba in the West, and they are culturally different in various ways. Nigeria is estmated to be over 202 million people as at November 2019 (World Population Review, 2019). Since the inception of the country, conflicts have dominated the political sphere, but this became more pronounced since 1960 after the independence. The return of Nigeria to democratic rule in 1999 has not changed the conflict situation instead it has continued to deepen each day with severe threat to national unity and development as various violent crimes seem to dominate the politics.

Nigeria is currently enmeshed in a myriad of socioeconomic, political and security problems which has severely affected the citizens wellbeing. Aside from the past scourging economic recession, poverty, unemployment, militancy, the Boko Haram insurgency, Fulani herdsmen terrorism, armed banditry, and kidnapping have taking over most communities in Nigeria in such prevalence and unprecedented manner as to question the capacity of government to protect her citizens. After the civil war, there has been an upsurge in violent crimes cum intensive use of sophisticated weapons resulting in massive killing and destruction of properties. Igbo (2007) was of the view that the end of the civil war in 
January 1970 witnessed the emergence and widespread utilization of firearms especially in robbery and violent crimes. The civil war provided the avenue for the acquisition and proliferation of sophisticated weapons in the hands of criminals.

Consequently, kidnapping, murder, rape, trans-border crime, cultism and militancy gained prominence in Nigeria. While efforts were being made to contend with the violent crime ushered in by the civil war, the Niger Delta criminal activities became another issue of global concern. In a related development, the Boko Haram saga started and created so much security challenges for Nigeria. Of recent, the activities of herdsmen have created many problems and threatened the peaceful co-existence and unity of the nation called Nigeria. The cumulative effect of the activities of violent criminals is that Nigeria has become very unsafe as human lives and properties are wantonly destroyed with impunity and government seemingly incapacitated to provide the needed security for her citizens.

The persistent killings and massive destruction of human lives and properties by herdsmen militia across the country has been pervasive for sometimes now without any respite (Adedeji, 2016). This is worrisome especially when it appears that government security agencies lack the wherewithal to contain the menace of Fulani herdsmen. This is clearly observed in the continuous victimization of the vulnerable population on daily basis without anyone to protect them. The situation has inevitably compelled many Nigerians to believe that government has no political will to address the problem of herdsmen in Nigeria, or Nigeria's security forces and allies are not adequately protecting the vulnerable population (Centre for Civilians in Conflict (CCC), 2015). Evidently, it is one of the biggest threats to global peace and stability in contemporary times; most especially when the Institute for Economic and Peace (2018) classified the group as the fourth deadliest terrorist organization globally. Since the dawn of this millennium, the incidence of terrorism has been on a steady rise worldwide. A few years ago, the problem of herdsmen victimization was in isolated places in the North- East, and North-Central Nigeria, but the situation has changed as the violent criminal activities carried out by herdsmen has spread rapidly across the states of Nigeria (Okey, 2013).

Scholars (Okolie \& Iorfyer, 2014; Olayaku, 2014) have shown that Fulani herdsmen have persistently carried out devastating violent attacks on vulnerable communities across the country with great devastation as if government security forces do not exist. The terrorist activities of Fulani herdsmen have become a global concern and great security threat especially following the remark by President Muhammadu Buhari and some of his aids that the terrorists referred to as Fulani herdsmen are not Nigerians but foreign militias who ran away from Mali, Somalia, Libya and infiltrated the ranks of the herdsmen (Akinrujomu, 2016; Ewubara, 2016). The security situation is even made complex by affirming that terrorists parading as herdsmen and causing mayhem across the country are foreigners, yet government seems unperturbed by that development. The states of Benue, Kaduna, Plateau, Nasarawa and Taraba seem to have been worst hit by the wanton destruction of Fulani herdsmen in Nigeria. The herdsmen are often seen moving around openly with sophisticated firearms with no security agency challenging them. They seem to be very powerful with firm hold on government that their criminal activities are seen as normal while citizens die in their hundreds and villages annihilated. It is on this background that Chinwokwu (2017) argued that the criminal activities of Fulani herdsmen have been glamorized by government body language which provides the platform for their criminal acts. Militant herdsmen often use machine guns and other sophisticated weapons to attack communities. Okpaga, Ugwu and Ene (2012) expressed dismay at the way and manner herdsmen spearhead onslaught on individuals, homes, livestocks, churches and mosques with impunity.

Olayoku (2014) opined that a recent observation of the activities of herders in Nigeria revealed that it has assumed a more lethal and sophisticated dimensions due to the nature of arms and ammunition deployed, the nature of magic involved, communication gadgets and casualties recorded. It has been observed that herdsmen migrate several kilometers, while taking violence to their victims. The attacks are sometimes carried out at night or early hours of the morning when unsuspecting victims least expect. Their activities have evidently destabilized the social, economic, religious and technological activities of many Nigerians.

With the rise and unregulated violent criminal activities of herdsmen, the resources of the victimized communities are threatened. Michael, Chinwokwu and Inyang (2017) while expanding on the negative, but unrestrained activities of herdsmen and its implications posited that the National Emergency Management Agency in Nigeria declared a total of 377,701 internally displaced persons (IDPs) as a result of herdsmen violent attacks across Northern Nigeria. Similarly, in July 2014, the International Organization for Migration (IOM) established a Displacement Tracking Matrix (DTM) to assist government in collecting and disseminating data on IDPs. In Benue state alone, over 1,500 people were killed in 47 violent attacks by Fulani herdsmen since 2015 (Iorhemen, 2018). Amnesty International reported that 549 people were killed in 2017 while 1,351 people were killed by Fulani herdsmen in 10 weeks between January 2018 and March 2018 (Godwin, 2018; Ndujihe \& Ugochukwu, 2018). As at April 2015, DTM recorded about 1,538,982 in North-East and NorthCentral Nigeria (Internal Displaced Monitoring Centre (IDMC), 2015). More worrisome is the observation of Ejiofor (2015) and IDMC (2015) that Nigeria has over 3.3 Million internally displaced persons and ranked $3^{\text {rd }}$ with the highest number of internally displaced persons in the world. Many of the displaced 
persons have found themselves in such conditions because of the criminal activities of herdsmen. Chinwokwu (2019) lamented that many Nigerians have become refugees in their own country that is not at war with another country due to the inhuman activities of Fulani herdsmen. In addition, over \#100 Billion Naira were lost due to their attacks (Iorhemen, 2018).

\section{Methodology}

This paper is basically a qualitative study which is dependent on secondary data. The study was carried out through the analysis of reports on herdsmen violent activities and victimization of the vulnerable in Nigeria and across Africa. Extant and relevant literature on bystander, victims of herdsmen terrorism and criminal justice system was reviewed with the objective of situating the problem.

\subsection{Conceptualizing Offenders, Victims and Bystanders of Violence in the Context of Herdsmen Victimization}

Offender: It is pertinent to understand that in any act of crime, there is always victimization, and the offender. Offenders are those who break the law. Smith (2013) maintained that an offender is anyone who commit or omit an act. $\mathrm{He}$ is the perpetrator of crime. An offender is a violator of societal norms, who either has been arrested, investigated, prosecuted or convicted. The offender is any person who has gone contrary to the norms of any given society whether arrested or yet to be arrested for the said violation. Societies with enormous socioeconomic challenges, the number of offenders will be relatively high (Wortley, 2010). The type of offenders differs, depending on the type and nature of offence. Clarke and Cornish (2003) asserted that, there are basically three types of offenders. These are:

Anti-social predators: These are the stereotypical, calculating criminals. They possess ingrained criminal dispositions and their offences involve premeditation and at least some rudimentary planning. They will typically enter the crime scene with pre-existing motivation to commit the crime, and their crimes are carried out intentionally and with a purpose. Their motivation for offending derives from the intrinsically rewarding nature of the crime they commit. Predators may specialize in a particular type of crime or may be criminally versatile, but in any event, all will have developed knowledge, skills and experience enough to minimize risk and effort and minimize payoff (Wortley, 2008). In this perspective, the herdsmen fall under this category because the violence orchestrated by them is premeditated and involve careful planning.

Mundane offenders: These are offenders with high level of ambiguity in their criminal involvement and opportunistic in their criminal enterprise. They engage in crime on occasional bases, crimes involved by them are of low-level (Iwarimie-jaja, 2012; Michael, 2010). Mundane offenders vary in their vulnerability to temptation, and hence in the extent of their criminal involvement, but overall both the seriousness and frequency of their offending is less than that of predatory offenders (Wortley, 2008).

Provoked offenders: These are reacting to a particular set of environmental circumstances such as situational frustration, irritation, social pressures and the like that induce them to commit crimes they would not have otherwise committed. Their involvement in crime may represent an aberration and would not have occurred if it were not for the precipitating events (Cornish \& Clarke, 2003).

The Fulani herdsmen are the offenders in the context of this paper and a little account of their socio-economic background will at this juncture suffice. The Fulani herdsmen are transhumance pastoralists, mainly dominant in Northern Nigeria. However, while the Fulani herdsmen had concentrated in Northern Nigeria, increased in population, exploitation of resources combined with increasing climatic changes especially from the 1980s onwards have compelled them to seek for greener pastures in the rainforest areas of Southern Nigeria (Okolie \& Ogayi, 2018; Odoh \& Chigozie, 2012). This has often brought the herdsmen into conflict with the vulnerable (host communities) especially when they go about destroying their crops and farmlands without remorse or compensation. Sometimes, the farmers poison their crops which kill livestock and in retaliation the herdsmen attack and kill members of the community. In some other times, the herdsmen will leave the area only to attack several weeks or years when the communities have forgotten about any dispute with them. The herdsmen seize the weakness of the community to attack them with the intent of dispossessing the natives of their farmlands and communities. This is why there are several internally displaced persons in Nigeria, because the herdsmen have taken over the lands in which they have killed the native and destroyed their homes. The irony is that the offender (herdsmen) have refused to accept modern livestock grazing system like ranching in order to avoid moving from place to place whereby they cause violence on vulnerable.

In the context of this paper the herdsmen are classified as predators, which victimize the vulnerable population with severe destruction. Michael (2010) in similar study identified some of the attributes of predators to include:

1. They have the ability and capability to defend their group against any attack

2. They are usually young, energetic and capable of committing violent crime

3. They possess some basic military training and must have been trained on warfare

4. They have in their possession sophisticated weapons to defend themselves against their purported enemies 
5. They have no respect for human dignity (life) and ever willing to take away life

6. They are usually aggressive and battle ready

7. They may or may not be citizens who carry prohibited firearms without licenses

8. They are mostly uneducated and can easily be manipulated by their recruiters.

9. They live on the periphery of society, and receive so little social support for their activities.

10. They are often strangers (Iwarimie-jaja, 2012), but with good local knowledge of the terrain they attack.

Victims: In every crime situation, there is always a victim. Iwarimie-jaja (2012) maintained that a victim is anyone, institution, place or property that has become the object of victimization. Victims are persons who individually or collectively have suffered harm, including physical or mental injury, emotional suffering, economic loss or substantial impairment of their fundamental rights, through acts or omission that are in violation of criminal laws operative within member states, including those laws proscribing criminal abuse of power. Victim may include the young, the adolescent, the poor, the minority, men and women including persons of all classes and occupational background. People of various socio-economic backgrounds usually fall victims of Fulani herdsmen violent attacks (Ikoh, 2014, Michael, 2010). Thus, social, economic psychological characteristics make some people more vulnerable to criminal victimization than others. Peterson (2015) observed that some populations are more vulnerable than others and disparity exist between individuals and communities in victimization rate. The criminal law recognized the victim of crime by prescribing punishment for the offender (Ikoh, 2014; Iwarimie-jaja, 2012). In developing nations including Nigeria, the victim of violent crime are mostly the poor and defenseless. Iwarimie-jaja (2012) has identified four types of victims of crime:

The innocent crime victim: This is the one who did not attract the offender to himself in any way. He happened to be there at the time the crime was to take place or he just fitted the likeness of the choice-victim who happened to be absent at the scene and at the time of the crime event.

The prone crime victim: This is often referred to as victims who are born to be victims. Often, it is because of their personal characteristics that make them to be more prone to certain crimes than other persons. Most victims of herdsmen attacks fall under this category because of their occupation.

The crime victim contributor: The victim contributed to his or her victimization. Girls who wear miniskirts are good examples of crime victim contributors.

The crime victim provocator: A victim whose actions are provocative, capable of causing another person or people to react angrily or in a violent manner as to result in crime against him or her. Sagarin and MacNamara (1975) were of the perception that victims are individuals and communities that can be victimized by criminals without the ability or the capability of government or community to protect them. It is possible to identify some of the characteristics of victims of herdsmen violent acts to include the following:

a. The victims lack the ability to defend themselves, members of their families and communities against any attack from herdsmen.

b. Most of the victims of herdsmen attacks are often children, women and the aged who are not strong enough to defend themselves. It is this state of physical weakness that makes them most vulnerable to the attacks especially when the attacks are carried out on them when they are asleep at night and unprepared to fight or defend themselves (if they can).

c. Some of the victims are weak due to pregnancies that have altered their physiological and anatomical being and functioning

d. Most of the victims are incapable to resist attack from herdsmen due to ill-health

e. They are weak and lack the capability to resist attack from herdsmen due to age and lack of experience.

f. The victims may lack basic military training and may not have prepared for such attacks.

g. Lack adequate and sophisticated weapons to defend themselves against any offender

h. The victims have respect for sanctity of life, thus may not be able to take any body's life

i. They are more likely to have what the offender wants or the offender so believes.

j. They live on the periphery of society, and receive so little social support for their activities (Michael, Chinwokwu, \& Inyang, 2017).

k. They are more often than not rural subsistence farmers whose only implements of work and defense are cutlasses and hoes which cannot stand against the sophisticated AK 47 rifles used by Fulani herdsmen.

1. In most cases, there are no known open dispute between the attacking Fulani herdsmen and their victims because the attacks are carried out for revenge of wrongs claimed to have been done to them by the local people in the past in which case the victims had long forgotten. On the other hand, it is a means of economic exploitation carried out to dispossess the local people of their ancestral farmlands. These descriptions aptly capture the victim of herdsmen attack in Nigeria and many developing nations of Africa.

Bystanders: The concept of bystander has been given different interpretation in extant literature (Latane \& Darley, 1968, Berkowits, 2002, Banyard, Plante \& Moynihan, 2004, Benyard, 2008). A bystander is a person who is near to crime events, but do not take active part in the criminal activity. Bystander includes any person, peer, or adult who becomes aware of crime and has an opportunity to help (Jones, Mitchel \& Turner, 2015). 
Iwariemie-jaja (2012)) sees a bystander as a person who is present when crime occurs, do not take active part in the criminal events but has the capability of preventing the criminal events from occurring but could not. In a more elaborate manner, a bystander of crime means any person, a group and institution that have knowledge of criminal activity, who is present or not when criminal activity occur, do not take active part in the criminal activity, but have the responsibility, ability and the capability to prevent such criminal activity, but intentionally or unintentionally refused to do so (Berkowitz, 2002; Benyard, 2008). From the definition so far, it is clear that a bystander of violence is any individual, group, organization who have knowledge of the purported violence, present or absence at the scene of the violence, do not take active part in the violence, have the ability to prevent the violence, but willing or unwillingly refused to prevent it (Faul, Aikman \& Sasser, 2016; Darley \& Latané, 1970). There are government officials, elected political office holders, security agents and some members of the community where violence is perpetrated by offenders. Scholars (Hudson \& Bruckman, 2014; Hart \& Miethe, 2008; Darley \& Latane, 1968; Benyard, 2008; Benyard et al, 2004; Jones et al, 2015) attempt to underscore the attributes of bystander of crime to include:

1. They have the capability to give direct or indirect assistance to the victim

2. They have the capability to report crime to appropriate legal authorities.

3. They are capable of sponsoring the crime for diverse reasons

4. They sometimes have a relationship with the offender and victim

5. They possess adequate resources to prevent criminal activities

6. They have the social responsibility to prevent criminal activities and protect the victim

7. In addition, some have been trained and equipped basically to protect the victims

8. Some are positioned by their duty posts to render assistance and protection to the victims.

Thus, Adogi (2009) argued that the victims consist of people who are more exposed to the harm of crime and violence caused by herdsmen (offender). In this regard, the weak in the society who have no one to protect them against savage attacks are the most vulnerable victims of violent activities of herdsmen militia (offender). These weak members of society are poor and lack the capacity or wherewithal to prevent their victimization especially because the attacks are carried out nocturnally in a surprise and attack style (gorilla warfare tactics).

The bystanders of violence such as security operatives, political leaders and other government agencies are not exonerated either because they are constitutionally mandated to render protection to victims of violent crime or they are trained and equipped to protect the weak but neglected to do so. They are charged with the responsibility of maintaining law and order and ensure the security of all persons. They are also authorized to arrest, charge and prosecute criminal offenders. Instead, they stand and watch victims helplessly killed by herdsmen. Indeed, it is alleged that the sophisticated weapons at the disposal of herdsmen could be provided by security forces because these categories of bystanders collude with the offenders covertly or overtly. This has raised serious questions on the integrity and capability of government in addressing various criminalities (murder, rape, kidnapping, armed robbery) associated with herdsmen. This is worsened by the allegation that some of the attackers wore military uniforms thereby complicating the neutrality of security forces in protecting vulnerable citizens. Pathetically, March, 2016 some 70 persons in Awgu, Enugu state who were trying to prevent Fulani herdsmen from raping their wives and daughters were arrested by the police while protecting the killer herdsmen (Akinkuotu, 2016). The bystanders (security forces) have deaf ears to the criminal activities of herdsmen thereby creating suspicions as to the motive of government and their attitude towards combating violent crimes in the country. This has placed the integrity and sincerity of government under intense scrutiny. On February 13, 2018 soldiers killed a vigilante named Efe Igbnovia while watching six herdsmen arrested for robbing passengers along Benin-Abraka expressway in IkpobaOkho Local Government Area, Edo State and the six suspected herdsmen were released by the soldiers (Okere, 2018).

\section{Theoretical Framework}

Two theories were adopted in this paper. These are the conspiracy theory and the routine activity theory

\subsection{The Conspiracy Theory}

This theory assumes that an event or situation that invokes an unwarranted conspiracy, generally one involving an illegal or harmful act carried out by government or other powerful actors. Barkun (2003) maintained that conspiracy theory rely on the view that the universe is governed by design, and embody three principles: nothing happens by accident, nothing is as it seems, and everything is connected. The theory is an effort to explain some event or practice by reference to the mechanization of powerful people who attempt to conceal their role at least until their aim is accomplished (Sunstein \& Vermeule, 2009, Sunstein, 2014, Clarke, 2002, Keeley, 1999). The hallmark of the theory is the assumption that for any event to occur two or more persons, a group and organization to be responsible for illegal or harmful event or situation (Barkun, 2011, Mark, 2008, Olsmted, 2011). The said event is collectively planned and executed, and the implication is detrimental to the group which the plan is targeted at. From the basic canon of the conspiracy theory, 
violent victimization of the residents of diverse communities by herdsmen in Nigeria is not accidental, but careful plan orchestrated by the herdsmen in collaboration with political leaders and security operatives. Security operatives have become tools in the hands of government who offer training to herdsmen, provide sophisticated weapons and provide security for them, while watching how such weapons are used to victimize civilian population. This non-constitutional responsibility of the security personnel is always carried out based on instruction from the few privileged class. The theory is criticized for over emphasis on the belief that every conspiracy is for negative activities.

\subsection{Routine Activity Theory (RAT)}

Felson and Cohen (1979) proposed that victimization is determined by the routine activity of individuals. Routine activity, according to the scholars refers to any recurrent and prevalent activity that provide for basic population and individual needs (Felson \& Cohen 1979). Cohen and Felson argue that crime as well as victimization occurs when these three factors: availability of suitable or vulnerable targets, absence of capable guardians against crime and victimization and presence of motivated offenders interface. This theory is used to explicate the differences in crime rates as well as the consequences of political, economic, social and cultural changes in regard to trends and patterns of crime commission in the society. Variations in the pattern of economic activities and opportunities will inevitably affect the rates of crime and victimization. From this theory it is viewed that people of diverse income, occupation, and age are vulnerable to victimization by criminals as they undertake their daily activities. The availability of herdsmen as potential criminals, the presence of the target such as potential victims and the absence of the security operatives, create a veritable platform for herdsmen to victimize the Nigerian people. The theory is challenged for assuming that all daily activities of people create room for their victimization (Michael, et al, 2017), although this has not been empirically tested. The criticism does not render it implausible in explaining the relationship between the offender, the victim and the bystander. The daily activities of herdsmen (offender), farmers (victims) are exacerbated because the bystander (security forces and government) failed to contain the activities of the offender.

\subsection{Chronicles of Herdsmen Victimization of the Communities in Nigeria between 2015-2017}

Almost every part of this country has suffered victimization from the violent activities of Fulani herdsmen militia. The intensity and pattern of Fulani herdsmen attacks on vulnerable communities is very alarming. The life of citizens has no meaning to average Fulani herdsmen as they value the life of cattle over human lives. For over a decade now, the activities of Boko Haram gained glogal recognition as they joined the league of terror groups worldwide (Smith, 2013). Although, the government of President Muhammadu Buhari claimed to have decimated the Boko Haram insurgents, emerging havoc being caused by them indicates a renaissance of a new deadly Boko Haram. Both Boko Haram and Fulani herdsmen have been acknowledeged and classified as deadly terrorist groups in the world (Institute for Economic and Peace (2018), yet government still shield herdsmen killers from arrest and prosecution. Fulani herdsmen have killed over 1,229 in 2014 while most of the attacks occurred just in six of the 36 states of Nigeria

Another quite impressive school of thoughts attributes the high incidence of herdsmen victimization of the vulnerable groups on resource scarcity and frustration aggression perspective. Abugu and Onuba (2015) while reasoning in frustration and aggression perspective posited that violent transgressions occur due to the accumulation of residual instigator effects of frustration. Aggressive behavior of the herdsmen is traceable to the resource depletion or scarcity which in the long-run affects their economic wellbeing. Frustration and aggression stem from resource scarcity and depletion. In such a situations, herdsmen often channel their frustration to the vulnerable groups which they consider have obstructed their migration to a safe place or must have been involved in rustling their cattle's. Irrespective of the triggers of herdsmen attacks, their activities are condemnable and criminally liable (Chinwokwu, 2019).

Documented evidence indicates that herdsmen victimization is considered one of the leading causes of violent death in Nigeria. From 2006 to 2014, about 615 cattle grazing related violent were witnessed, in a total of 61,314 violent attacks in Nigeria (Olayoku, 2014). A chronicle of the sporadic incidents of herdsmen victimization in Nigeria between 2015 and 2017 is shown in the Table 1 
Table 1. Herdsmen victimization of communities in 2015-2017

\begin{tabular}{|c|c|c|c|c|}
\hline $\mathbf{S} / \mathbf{N}$ & Date & Town & LGA/States & No of Victims \\
\hline 1 & 03/01/2015 & Ambe-madaki & Sanga, Kaduna & 15 \\
\hline 2 & 03/01/2015 & Shurun & Mangu, Plateau & 10 \\
\hline 3 & $23 / 01 / 2015$ & Lissam & Ussa, Taraba & 12 \\
\hline 4 & $27 / 01 / 2015$ & Yangal-fadan & Zango-Kafat, Kaduna & 18 \\
\hline 5 & $29 / 01 / 2015$ & Nwonko & Wukari, Taraba State & 30 \\
\hline 6 & $15 / 03 / 2015$ & Egba & Agatu, Benue & 90 \\
\hline 7 & $20 / 04 / 2015$ & Donga & Donga, Taraba & 7 \\
\hline 8 & $25 / 04 / 2015$ & Barkin Ladi & Barkin \& Riyom, Plateau & 70 \\
\hline 9 & $15 / 05 / 2015$ & Shengeo & Gwer West, Benue & 8,1000 displaced \\
\hline 10 & $19 / 05 / 2015$ & Barkin Ladi & Barkin Ladi, Plateau & 27 \\
\hline 11 & $24 / 05 / 2015$ & Ukura Gafa per etc & Logo, Benue & Above 100 \\
\hline 12 & $04 / 07 / 2015$ & Barkin Ladi & Barkin Ladi, Plateau & 2 \\
\hline 13 & $11 / 07 / 2015$ & Dananacha & Gassol, Taraba & 24 \\
\hline 14 & $12 / 07 / 2015$ & Kofar Gwari & Kokona, Nasarawa & 5 \\
\hline 15 & $14 / 07 / 2015$ & Dagari & Gassol, Taraba & 2 \\
\hline 16 & $17 / 07 / 2015$ & Katsina Ala & Katsina Ala, Benue & 13 \\
\hline 17 & $19 / 07 / 2015$ & Kofar Gwari & Kokona, Nasarawa & 2 \\
\hline 18 & $31 / 07 / 2015$ & Ropp & Ropp, Pleteau & 1 \\
\hline 19 & 08/07/2015 & Dananacha & Gassol, Taraba & 2 \\
\hline 20 & $28 / 08 / 2015$ & Fan-Nding & Ropp, Plateau & 2 \\
\hline 21 & $30 / 08 / 2015$ & Dorong & Foron, Plateau & 2 \\
\hline 22 & $30 / 08 / 2015$ & Joi & Barkin Ladi, Plateau & 2 \\
\hline 23 & $31 / 08 / 2015$ & Tanti & Bokkos, Plateau & 5 \\
\hline 24 & 03/09/2015 & Bachit & Riyom, Plateau & 1 \\
\hline 25 & 03/09/2015 & Sho-Barkin Ladi & Barkin Ladi, Plateau & 5 \\
\hline 26 & 06/09/2015 & Kortse & Gassol, Taraba & 2 \\
\hline 27. & $06 / 09 / 2015$ & Riyom & Riyom, Plateau & 3 \\
\hline 28. & $09 / 09 / 2015$ & Kwi & Riyom, Plateau & 2 \\
\hline 29 & $10 / 09 / 2015$ & Asema Pever & Gassol, Taraba & 1 \\
\hline 30 & $12 / 09 / 2015$ & Sarkin Kudu & Ibi, Taraba & 10 \\
\hline 31 & $13 / 09 / 2015$ & Zakupwany & Barkin Ladi, Plateau & 20 \\
\hline 32. & $13 / 09 / 2015$ & Donga & Donga, Taraba & 6 \\
\hline 33 & $15 / 09 / 2015$ & Ibi & Ibi, Taraba & 9 \\
\hline 34 & $15 / 09 / 2015$ & Mangu & Mangu, Plateau & 18 \\
\hline 35 & $01 / 01 / 2016$ & Nkanu East & Nkanu East, Enugu & 1 \\
\hline 36 & $01 / 01 / 2016$ & Nasarawa & Nasarawa & 12 \\
\hline 37 & $10 / 01 / 2016$ & Agatu & Agatu, Benue & 45 \\
\hline 38 & $17 / 01 / 2016$ & Wukari & Wukari, Taraba & 0 \\
\hline 39 & $25 / 01 / 2016$ & Gojefa & Numan, Adamawa & 20 \\
\hline 40 & 06/02/2016 & Buruku & Buruku, Benue & 12 \\
\hline 41 & $07 / 02 / 2016$ & Yawa North & Ogun & 1 \\
\hline 42 & $07 / 02 / 2016$ & Buruku & Buruku, Benue & 10 \\
\hline 43 & $11 / 02 / 2016$ & Uzo Uwari & Enugu & 2 \\
\hline 44 & $24 / 02 / 2016$ & Agatu & Agatu, Benue & 300 \\
\hline 45 & $27 / 02 / 2016$ & Wukari & Wukari, Taraba & 9 \\
\hline
\end{tabular}


Table 1 Continued

\begin{tabular}{|c|c|c|c|c|}
\hline 46 & $28 / 02 / 2016$ & Agatu & Agatu, Benue & 9 \\
\hline 47 & $03 / 03 / 2016$ & Logo & Logo, Benue & 1 \\
\hline 48 & $05 / 03 / 2016$ & Agatu & Agatu, Benue & 0 \\
\hline 49 & $08 / 03 / 2016$ & Logo & Logo, Benue & 40 \\
\hline 50 & 08/03/2016 & Buruku & Buruku, Benue & 12 \\
\hline 51 & $09 / 03 / 2016$ & Logo & Logo, Benue & 8 \\
\hline 52 & $10 / 03 / 2016$ & Agatu & Agatu, Benue & 2 \\
\hline 53 & $13 / 03 / 2016$ & Agatu & Agatu, Benue & 90 \\
\hline 54 & $13 / 03 / 2016$ & Buruku & Buruku, Benue & 2 \\
\hline 55 & $13 / 03 / 2016$ & Tarkaa & Tarkaa, Benue & 6 \\
\hline 56 & $17 / 03 / 2016$ & Logo & Logo, Benue & 25 \\
\hline 57 & $17 / 03 / 2016$ & Buruku & Buruku, Benue & 15 \\
\hline 58 & $19 / 03 / 2016$ & Udi & Udi, Enugu & 1 \\
\hline 59 & $21 / 03 / 2016$ & Guma & Guma, Benue & 2 \\
\hline 60 & $29 / 03 / 2016$ & Ogba-Egebema & Ogba-Egebema Rivers & 7 \\
\hline 61 & $04 / 04 / 2016$ & Tarkaa & Tarkaa, Benue & 1 \\
\hline 62 & 09/04/2016 & Oktipupa & Oktipupa, Ondo & 1 \\
\hline 63 & $12 / 04 / 2016$ & Gashaka & Gashaka, Taraba & 15 \\
\hline 64 & $13 / 04 / 2016$ & Bali & Bali, Taraba & 44 \\
\hline 65 & $13 / 04 / 2016$ & Ifedore, & Ifedore, Ondo & 0 \\
\hline 66 & $16 / 04 / 2016$ & Ayamelum & Ayamelum, Anamabra & 1 \\
\hline 67 & $18 / 04 / 2016$ & Kwande, & Kwande, Benue & 18 \\
\hline 68 & $25 / 04 / 2016$ & Nkpabi Nimbo & Uzo-Uwan, Enugu & 57 \\
\hline 69 & $26 / 04 / 2016$ & Ndokwa & Ndokwa, Delta & 0 \\
\hline 70 & $27 / 04 / 2016$ & Ozo-Uwani & Uzo-Uwani, Enugu & 20 \\
\hline 71 & $16 / 06 / 2016$ & Ossissa & Ndokwa East, Delta & 1 \\
\hline 72 & $20 / 06 / 2016$ & Logo & Logo, Benue & 59 \\
\hline 73 & $25 / 07 / 2016$ & Gaambe-Tiev & Logo, Benue & 14 \\
\hline 74 & $20 / 08 / 2016$ & Barkin Ladi & Barkin, Pleteau & 2 \\
\hline 75 & $25 / 08 / 2016$ & Attakwu & Nkanu West, Enugu & 3 \\
\hline 76 & $12 / 01 / 2017$ & Sabon Daga & Bosso, Niger & 3 \\
\hline 77 & $20 / 03 / 2017$ & Zaki Biam & Zki Ibiam, Benue & 30 \\
\hline 78 & 03/04/2017 & Kwande & Kwande, Benue & 15 \\
\hline 79 & $14 / 05 / 2017$ & Etiogi & Mokwa, Niger & 21 \\
\hline 80 & $19 / 07 / 2017$ & Kujuru & Kaduna, Kaduna & 33 \\
\hline 81 & 08/09/2017 & Bassa & Bassa, Plateau & 34 \\
\hline 82 & $15 / 10 / 2017$ & Miango & Bassa, Plateau & 29 \\
\hline 83 & $17 / 11 / 2017$ & Irigwe & Bassa, Plateau & 41 \\
\hline
\end{tabular}

Source: Chinwokwu, 2019, p.43; Godwin, 2018; Ndujihe \& Ugochukwu, 2018 


\subsection{The Relationship between Offenders and Victims in the Context of Herdsmen Victimization}

Proceeding from the conceptualization of offenders and victims, the herdsman is perpetual and die-hearted group that victimize the vulnerable population. The victims are residents who suffer victimization from herdsman. Alagu (2009) asserts that victims of herdsmen violence often have a relationship with the herdsmen, but the relationship is not always harmonious. Elsewhere, Michael et al., (2017) had established the unfriendly nexus between offenders or perpetrators of violence and their victims. The herdsmen are armed with sophisticated weapons than their victims. Herdsmen from the offenders' perspective must have precipitating events to blame the victims before unleashing their attack on the victim (Cornish \& Clarke, 2003).

Expanding on the correlation between herdsmen and victims of violence, Peterson (2015) observed that there exists a rancorous relationship between herdsmen and residents who have become objective of victimization. Smith (2013) subscribed to the perception that herdsmen and victimized communities have developed negative and bitter feelings which have enormous implication on future relationship. In attempt to explain the nature of the relationship existing between herdsmen and victims of violence, Agbedo (2016) opined that both groups have developed insurmountable suspicion. The herdsmen often suspect the residents for engaging in cattle rustling, preventing them from grazing their cattle while the residents in turn suspect the herdsmen for violent crimes, ranging from rape, kidnapping and violent death perpetrated against the communities. Igomu (2016) asserted that often victimized communities blame the herdsmen for their victimization. The level of suspicion between the herdsmen and the communities in Nigeria has been acknowledged by many scholars. Adedeji (2016) of particular note revealed that almost all communities that have witnessed incidence of violent crime being allegedly perpetrated by criminal elements among herdsmen have developed high level of suspicion and dislike for herders including gentle and law abiding ones. The level of suspicion is exemplified in the deliberate refusal of many communities to welcome herders in their locality. The relationship between herdsmen and the victims could be explained further from the following proposed hypotheses:

1. Strong-weak hypothesis: The strong-weak hypothesis is premised on the assumption that the herdsmen are stronger while the communities they victimize are weaker in the context of violent victimization. The strong-weak hypothesis assumes that the herdsmen are considered to be stronger than their victims. The herdsmen are more energetic, in possession of sophisticated weapons, have good experience in the use of weapons and how to defend themselves. This hypothesis stems from the perception that herdsmen take on communities only when in possession of adequate weapons that can undo the defense of their assumed enemies. On the other hand, many of the victimized communities are vulnerable population who may not have the capability of defending themselves. They comprise of pregnant women, the aged, the sick and children. This population is considered weak, when compared to the herdsmen. The strong-weak hypothesis was buttressed by Akin (2017) that herdsmen have repeatedly overpowered the security operatives, killing the police and members of Nigeria Security and Civil Defence Corps, before proceeding to attack other members of the communities. The hypothesis is also exemplified in the diverse attack by members of the Boko Haram sects, who have severally attack security operatives and overpowered them because of the nature of weapons at their disposal. If the security personnel trained for several years with tax payers' money and armed could be overpowered, then the situation of the vulnerable population is more pathetic.

2. Prepared-unprepared hypothesis: The preparedunprepared hypothesis assumes that herdsmen attack communities well prepared while the victimized populations are always unprepared. The herdsmen take time to plan and organize the attack before execution. Smith (2016) reveals that herdsmen attack communities after several days, weeks and month of preparations. This account for while most of the violence staged by herders are successful. They take on residents when some of them have gone to bed and early hours of the morning. It is most likely that the herdsmen skillfully and tactically take time to plan their heinous and nefarious criminal activities before they execute it. The violent herdsmen take adequate time to plan their atrocities. Ahmed (2014) buttress the view, when he noted that any attack on herdsmen can never be forgiven and forgotten. There must be retaliation in future, irrespective of the months, and years it takes. Herdsmen after several days, weeks, and months of premeditation, calculation, organization and re-strategizing will come to attack the purported communities. Herdsmen militia earmark communities acquire arms, receive training on how to use the arms, hire mercenaries, and work out modalities on how to get the support of the bystanders before victimizing their acclaimed enemies. On the contrary, the victimized communities are always taken unawares. The communities do not always expect such attack and thus never prepared. Nwankwo (2015) reveals the craftiness of the herdsmen, who victimized communities when such communities do not have the premonition that such attack, will come. This make the community not prepared for such eventualities. A cursory look at the several attack by herdsmen in Nigeria, revealed that their victims are often taken unawares. Often the attack comes when the law abiding members of the 
community are asleep, involved in religious rituals, burial and other social activities.

3. Selective-unselective hypothesis: The selectiveunselective hypothesis assumes that herdsmen carefully select actors that will participate in the violence. Not all the herdsmen are involved in the attack. Smith (2016) maintained that the herders' wives, aged and the children do not take active part in the violence. The participants in the attack are the young and energetic youths who are capable of perpetrating such violence and can withstand a reprisal attack from any group. They could be hired and battle-ready. However, the victimization is not selective; men, women and children are all victims of herdsmen attack. Peterson (2015) observed that when the blood littering herdsmen approach any community, no human is spared and properties can be destroyed without reservation. The way innocent children, the aged, pregnant women and those with health challenge are destroyed without hesitation in many communities in Nigeria by herdsmen is worrisome. Adogi (2013) observed that herdsmen are very destructive. They destroy all categories of human lives and properties without remorse. The three hypotheses presented in this paper are our contributions to knowledge and understanding of the herder, farmer and government forces relationship in Nigeria in relation to the killings of farmers by hredsmen. It is this relationship that defines definite actions of the offenders (herdsmen) and bystanders of violence (government security forces) and the probable reason the weak and vulnerable in the society are brazenly victimized without respite.

\subsection{The Nexus between Offenders and Bystanders in the Context of Herdsmen Victimization}

There exists a strong relationship between offenders and bystanders in violent activities orchestrated by herdsmen in Nigeria. The mutual cooperation that exists in most instances compelled the public to doubt the sincerity of government in addressing the problem of herdsmen victimization. Herdsmen more often than not received support from the bystanders of violence which likely encourage them to operate without fear. The source further alleged that most of the sophisticated weapons at the disposal of herdsmen are provided by government officials, political leaders and security agents. This allegation must not be unconnected with the nonchalant attitude of government towards herdsmen criminalities. More importantly, El-Rufai the Governor of Kaduna State said he paid off the Fulani herdsmen to stop them from further killings in Southern Kaduna (Yusuf, 2016). This confessional statement is a manifestation of how Fulani herdsmen are supported encouraged and empowered by politicians or government officials without any recourse to the feelings of the victims. Perhaps, this is because the government in power is controlled by a Fulani man and a patron of the Fulani herders. In an attempt to explain and discuss the nature of the relationship that exists between herdsmen and bystanders (political leaders and security agents), we proposed the Support-acceptance hypothesis as contribution to knowledge and understanding of this subject matter.

The Support-acceptance hypothesis is premised on the perception that government, political leaders and security agents' work in a collaborative form to provide the necessary support for the herdsmen to victimize residents of diverse communities for some political, social, religious and economic interest. The support analysis uncovered the extent at which leaders and security agents directly or indirectly work with herdsmen to victimize the vulnerable group. Akanji (2015) while amplifying this perspective argued that it is well known fact that bystanders to provide financial support, logistics, weapons and ensure the security operatives do not molest any of the herdsmen while victimizing their enemies. In a related observation, Ebienfa (2014) insists that government and security agents have refused to take a drastic action against herdsmen identified as the fourth most dreaded terrorist group in the world (Institute for Economic and Peace, (2018) therefore; its supportive role is glaring. International Crisis Group (2018) described the conflict between herders and farmers in Nigeria as six times deadlier in 2018 than Boko Haram's insurgency. It stated that 1,300 people have been killed within six months (January 2018 and June 2018), while over 300,000 are estimated to have fled their homes within the period. It also stated that since September 2017 about 1,500 people have been killed by herdsmen militia without government action. Peterson (2015) interrogated the situation further and was bold to insist that Nigeria's political elites and security operatives were supportive of the nefarious activities of herdsmen and other terror group via their incapacity to address the menace headstrong. This is even clearer as the umbrella organization of the herdsmen, the Miyetti Allah now talks tough who becomes what in the political arena. It is more worrisome that even after the international community's had branded the herdsmen as terror group, the Federal Government of Nigeria see nothing wrong with their heinous activities, but rather prefer to label the Independent People of Biafra (IPOB) who do not possess such sophisticated weapons like herdsmen as terror group. A careful observation of the recurrent and lethal nature of attack by herdsmen, without any drastic effort from the government, political leaders and security agents shows that the above actors are in supports of the persistent victimization of the vulnerable population. Most pathetically with indication that government are giving herdsmen soft landing is the fact that on June 13, 2018 five Christians were sentenced to death by hanging for killing a herdsman by Justice AbdulAzeez Waari of Yola High Court in Adamawa State (Umar, 
2018), yet no herdsman has been arrested or prosecuted for all their atrocities.

Wantu (2015), Agbedo (2016) and Igamu (2016) are of the view that government on their part had not taken up their constitutional responsibility of providing security for vulnerable communities. It is worrisome that some leaders for political interest could arm the herdsmen to kill, destroy and displace a community to pave way for their political interest. If government officials saddled with the responsibility of providing security for the vulnerable could in turn armed a group of criminals to kill others for their selfish interest, then, development is far from Nigeria. Nigerians, especially leaders will always condemn the activities of herdsmen on the pages of newspapers and social media without adequate policy measure to prevent reoccurrence.

Similarly, while the offenders (herdsmen) receive financial, moral and logistic support from government, political leaders and security operatives to victimize innocent Nigerians, the herdsmen must accept and adhere to the instructions provided by the bystanders. The offenders (herdsmen) must adhere strictly to all the necessary instructions. Such instructions may bother on which community to attack, the route to take, when to attack and nature of the attack. The Support-acceptance hypothesis established that while the bystanders provide all that is required for the attack, the herdsmen must adhere to the norms of the deal. The government, political leaders and security agents collaboratively commission herdsmen to attack the communities which are of interest to them (bystanders). Okoli and Atelhe (2014) had earlier amplified this situation, that some of the recurrent attacks by herdsmen have political undertone. In Nigeria, the desperation to hold political positions, could compel leaders to ensure that communities they are not sure of support is destabilized before the election through violent activities orchestrated by herdsmen. It is imperative to note that the violence which Eggon people had witnessed in the recent past resulting from Fulani herdsmen attacks have enormous political colorations. In line with the Supportacceptance hypothesis, Peterson (2015) argued that in order to achieve success in the victimization process, herdsmen must adhere to the instructions provided by their sponsors (government officials, political class and security agents). The rationale for such adherence is to ensure that nothing goes wrong with the process of preventing arrest and prosecution (Peterson, 2015). From another perspective, Smith (2016) asserted that instructions provided by the bystanders for the herdsmen on the type of the attire to put on during the attack must be obeyed. Often, herdsmen and other terror groups disguise themselves in military uniform as this will enable them attack without molestation. The Support-acceptance hypothesis has continued to promote the culture of violence with enormous implications on the socio-economic development of Nigeria. The understanding of this hypothesis will help our knowledge of governance and administration of the criminal justice system which seems lukewarm in dealing with the issue of herdsmen criminality. It is imperative to mention that over a decade the issue of herdsmen terrorist acts manifested in the landscape of Nigeria, government and their agencies have not arrested and prosecuted a single offender in spite of the momentum of their killings and other atrocities across the country. The President's body language as a Fulani man seems to be the underlying reason why the criminal justice system has comatose in tackling herdsmen criminal activities decisively.

\subsection{Link between Victims and Bystanders of Violence in the Context of Herdsmen Victimization}

The relationship between victims and bystanders of violence is surrounded by suspicion and distrust (Smith, 2013). Drawing our intellectual inspiration from the work of Smith, we developed the deceit-distrust hypothesis. The central idea in the deceit-distrust hypothesis is that communities that have been victimized by herdsmen including those that have the potential of being victimized have developed distrust for government and security agents and doubt the sincerity of the social actors in securing them. The deceit-distrust uncovers the insincerity on the part of government and security agents in providing security for the vulnerable population. The government deceptive mechanism is always employed on the pages of newspapers and other available channels of communications on how the security agents are contending with the violent herdsmen. The recent handling of security related problems has clearly shown that government and security agents were rather recruited to protect the privileged class and not the majority of the masses. Adedeji (2016) observed that in the several attacks by herdsmen in Nigeria, security agents will be practically present and the herdsmen will attack communities without interruption.

In some situations, it is after the assailants had left the scene of violence that the security agents will appear. In most cases, distress call on the security operatives will never be attended to for some irrational reasons. The population that suffers physical, social, psychological and economic harm of violence has developed a negative opinion about the government, political class and security operatives. Communities with previous experiences of victimization, without protection from government and security operatives will certainly form the opinion that every effort by government to protect them was deceptive. Nwankwo (2015) observed the deceptive mechanism employed by government in managing crises in Nigeria. Even when our institutions are weak and lack the capacity to address many of our problems including security challenges, government will hire men and women who are sympathetic of the system to deceive Nigerians on what the government is doing to address the problem. In the context of herdsmen violence, the victims have developed and see government as employing deceptive mechanism to inform Nigerians that it is addressing the problem of insecurity 
orchestrated by government, while the activities of the herdsmen are on the increase, considering the nature and extent of attacks in recent times.

On the other hand, the bystander's lack of trust for community's support during elections could prevent them from securing such communities. At any point in time, when political leaders considered that particular communities will not support their candidature, and their support for another candidate will jeopardized their chances of winning the elections, they may resort to violence by sponsoring criminals to create violence in such communities. The essence of such violence is to create panic and election apathy. This has been witnessed in many communities in Nigeria. Iheajiamizu (2002) asserts that the desperation for material wealth and political positions is capable of compelling many Nigerians to do the unthinkable. Obasanjo (2002) observed this situation earlier that we fight and sometimes shed blood to achieve and attain political power because for us in Nigeria, the political kingdom has for long been the gateway to economic kingdom. On this note, bystanders (politicians) could equip herdsmen with firearms for violent activities including the killing of residents of diverse communities. From this perspective, while the residents of diverse communities see the deception on the part of the bystanders in securing them against herdsmen attack, the bystander on their part believed that if the communities remain in tranquility, such communities may not support them during elections. The refusal to support them may tantamount to them not winning the elections. Thus, the bystander could orchestrate violence using the herdsmen. Government has all the institutions and resources at her disposal. Government controls the security architecture of the state. With the enormous power at its disposal, it can do the unthinkable using different modalities. At any point government and other political leaders consider a particular community unsympathetic, especially as it bothers on election matters, it could sponsor violence to create fear and prevent the masses from participating in the elections in such communities. The essence is to ensure the will and the decision of the electorate which may be unfavourable to them is distorted.

\subsection{Implications for Criminal Justice System}

The relationships among herdsmen, victims and bystanders in the context of herdsmen victimization have great implications on criminal justice and democratic principles. For many years of herdsmen wanton destructions of lives and properties, there has been rarely any arrest of the suspected culprits. Iwariemie-jaja (2002) described arrest as a police process of depriving a suspect of his liberty, such suspect is taken into custody for the purpose of charging him formally with an offence suspected to have been committed by him or some other person for whom he has knowledge or connection. Like in many other criminal activities where suspects are never arrested, investigated or prosecuted, so is the case of violent crimes perpetrated by suspected herdsmen (Michael, Inyang \& Ukpong, 2017). The inability of security agents to arrest the suspected herdsmen and prosecute them accordingly, has created a platform for continuous attack by the criminal elements. This is because of the nature of the relationship that exists between the herdsmen and bystanders (formal security forces). This has inevitably questioned the existence and operation of the Criminal Justice System (CJS). Michael (2010) had earlier alarmed that suspected criminals who have political affiliation are often not arrested for prosecution and the implication on the CJS is quite detrimental. Similarly, Chinwokwu (2017) elsewhere observed that government silence and glamorization of Fulani herdsmen violent activities offered the leverage for their criminal impunity and incapacitation of the criminal justice system. It is also on record that Governor Nasir El-Rufai of Kaduna state gave huge sums of money to the Fulani herdsmen militia to prevent them from further attacks without arresting them (Yusuf, 2016).

Criminals sponsored and commissioned by political leaders and security operatives cannot be arrested. A recent observation by Smith (2017) revealed that security operatives' partner indirectly with criminals to attack communities, thereafter, no arrest or investigation is ever carried out. The source further asserted that in a society where the security operatives connived with criminals to perpetuate violence on vulnerable communities, the CJS is seriously affected. This is clearly witnessed in Nigeria where after series of attack by herdsmen; no sincere arrest has been made, thereby leaving so many implications on the CJS. Once no suspect has been arrested, there is no room for investigations or prosecution. Often, when herdsmen strike, the bystanders will vehemently claim investigations will be carried out. Most times, such investigations end on the pages of newspapers. The claim of government to fight herdsmen seems a hoax as they continue ravaging the country with terror and destruction.

\section{Conclusions}

This paper established the upsurge in violence orchestrated by herdsmen. It is the position of this paper that the herdsmen could have supports from the government, political leaders and security operatives to victimize the people of diverse communities in Nigeria. The main purpose for the victimization of vulnerable communities is for economic, social, cultural and most especially political reasons. Perhaps also, it is a sheer exclusion of vulnerable from election through orchestrated violence by herdsmen for the advantage of the ruling government. The upsurge in the violence has shown that there is mutual cooperation between the herdsmen, government, security operatives and political leaders in the 
victimization process. On the other hand, there is evidence of deceit and distrust between government, political leaders, security operatives and victims of violence. The herdsmen and victims relationships are engulfed with bitterness and rancour. The impact of the nature of relationship among these social actors involved in violence on arrest, investigation and prosecution is detrimental to the development of the criminal justice system in particular and the Nigerian society in general. The perceived relationship between herdsmen and government has further polarized ethnic groups in Nigeria and worsened insecurity in the country especially when the head of government and most sensitive security positions are held by Fulani extract it strengthens the political factor in Fulani herdsmen terrorism. Most importantly, as long as people who commit crime are not punished by government, the criminals get encouraged to continue in their criminality. This is the oxygen that has been fueling the criminal activities of Fulani herdsmen.

\section{Recommendations}

Based on the findings, the following recommendations were advanced.

i) The government at all levels should ensure that their constitutional responsibility of providing the masses with adequate security irrespective of their religious and ethnic differences is strictly adhered to.

ii) Community leaders in partnership with state government should commission neighbourhood watch group that will assist in providing security for the residents of rural areas.

iii) The civil society organization should ensure that previous attacks by herdsmen are properly investigated and report made public, independent of government interference.

iv) Members of the community should be careful in approaching enmass individuals who appear in their community on government security uniforms in order to mitigate casualties that may result if they are attackers. They should set up surveillance groups in their communities whose duty will be to identify genuine and fake security men in uniform in their communities before receiving such persons in their midst.

v) Community leaders must ensure that indiscriminate and unregulated accommodation of herdsmen in their communities is stop forth with.

vi) The electorate must develop the culture of holding their leaders and representatives accountable. This will make them fulfill their constitutional responsibility of ensuring that people are properly secured.

vii) The international community should constitute an independent body devoid of government and political leaders' interference to investigate the nature of herdsmen victimization and the source of their weapons in Nigeria.

viii) Government should be courageous enough to take decisive action to criminalize open grazing and Miyetti Allah Association in order to contain the violent nature of herdsmen and prevent future catastrophe that may lead to Nigeria's disintegration. This must be done if government is sincere and committed in combating the menace and maintaining the oneness of Nigeria.

ix) Existing laws on criminal trespass should be strengthened and stringent punishment meted on offenders devoid of ethno-religious bias. Government must enact laws which proclaims the responsibility of the safety of citizens on the government and exclusively deals with the victimization of the poor and helpless through restorative justice system.

$\mathrm{x})$ The civil society must demand from government positive and decisive actions to end herdsmen wanton destruction by activating the instruments of the criminal justice system which hitherto had been nonchalant towards the activities of Fulani herdsmen violent activities. This is because government failure to arrest and prosecute the group has provided the backbone for their criminality.

\section{REFERENCES}

[1] Abbas, I. M. (2000). No Retreat, no surrender: Conflict for survival between Fulani pastoralists and farmers in Northern Nigeria.European Scientific Journal, 8(1), 331346.

[2] Abugu, S.O. \& Onuba, C.O. (2015). Climate change and pastoral conflicts on the middle belt and South-east Nigeria: Implication on human resource of the region. Global Journal of Human Resource Management, 5 (5), 44-51

[3] Ademola, A., \& Ademola, F. (2012). Ecology of fear. New York: Sage Publishers

[4] Adedeji, P.A. (2016). Socio-economic effects of Farmers/herders conflict in Obi Local Government Area. Unpublished B.Sc Project, submitted to the Department of Sociology, Nasarawa State University, Keffi.

[5] Adogi, M. (2013). Fulani-farmers conflicts in Nasarawa State: The ecology, population and politics. Abuja: Murry Greens Consult.

[6] Agbedo, O. (2016, March 7). Tracking endless Fulani herdsmen/farmers clashes. The Sun Newspapers, p.12

[7] Akanji, O. O. (2015). Security crisis in Nigeria: Boko Haram insurgency and the prospects of peace. Conflict Studies Quarterly Special Issue, 5, 58-73

[8] Akinrujomi, A. (2016). Buhari blames Mali, Libya for Fulani herdsmen attacks. Retrieved from http://www.naij.com/10 55833-long-silence-bujari-makes-shocking-excuse-fulaniherdsmen-killings.html 
[9] Akinkuotu, E. (2016). Herdsmen recorded video of Enugu massacre - police. Retrieved from: http://punchng.com/her dsmen-recorded-video-enugu-massacre-police/ on April 2, 2018

[10] Akpan, N. S. (2010). Kidnapping in Nigeria's Niger Delta: An exploratory study. Journal of Social Science, 24(1), 3342

[11] Badejo, B. R. (1989). Multilingualism in Sub-Sahara Africa. African Media Review. 3(2), 40-53

[12] Barkun, M. (2003). A culture of conspiracy: Apocalyptic visions in contemporary America. Berkeley: University of California Press

[13] Barkun, M. (2011). Chasing phantoms: Reality, imagination, and home land security since 9/11. Chapel Hill: University of North Carolina Press.

[14] Banyard, V.T (2008). Measurement and correlation of proposal bystander behavior: The case of interpersonal violence. Violence and Victims, 23 (1), 83-97.

[15] Banyard, V.L., Plante, E. a; \& Moynitian, M. (2004). Bystander education: Bringing a broader community perspective to sexual violence prevention. Journal of Community Psychology, 32 (1), 61-79.

[16] Berkowitz, A. D. (2002). Fostering men's responsibility for preventing sexual assault, in preventing violence in relationships: Intervention across the life span. Washington; DC: American Psychological Association.

[17] Blench, R., \& Dendo, M. (2010). Conflict between pastoralists and cultivators in Nigeria. London: DFID

[18] Center for Civilians in Conflict (2015). When we can't see the enemy, civilians become the enemy. Available at www.civiliansinconflict.org

[19] Chinwokwu, E. C. (2017). Glamorization of Fulani herdsmen's criminality and its implications on national security in Nigeria. Online Journal of Arts, Management and Social Science, 2(2), 29-51

[20] Chinwokwu, E. C. (2019). Herdsmen terrorism and criminal justice in Nigeria: Implications for social order and development. Journal of Management, Social Sciences, Peace and Conflict Studies, 2(1), 25-45

[21] Clarke, S. (2002). Conspiracy theories and conspiracy theorizing. Philosophy of the social Sciences, 32 (2), 131150 .

[22] Cohen, L. M. \& Felson, M. (1979). Social change and crime: A routine activities approach. American Sociological Review, 44, 588-608

[23] Cornish, D.B \& Clarke, R.V. (2003).Opportunities, precipitators and criminal decisions: A reply to Wortley's critique of situational crime prevention. In M. Smith, \& D. Cornish (Eds.). Theory for practice in situational crime prevention. Crime Prevention Studies (pp.234-245). New York: Criminal Justice Press.

[24] Darley, J. M. \& Latané, B. (1968). Bystander intervention in emergencies: Diffusion of responsibility. Journal of Personality and Social Psychology, 8, 377-383

[25] Darley, J. M. \& Latane, B. (1970). The unresponsive bystander: Why doesn't he help? New York: Appleton Century Crofts.

[26] Ebienfa, K. I. (2011). Militancy in the Niger Delta and the emergent categories. Review of African Political Economy, 38 (130), 637-643

[27] Ejiofor, C. (2015). Nigeria has 3.3 million persons displaced by conflict-the highest number in Africa. Retrieved from http://www.internal-

displacement.org/assets/publication/2014/201405-globaloverview-2014-en-pdf.

[28] Ewubare, K. (2016). Herdsmen from Libya responsible for attacks-Buhari. http://www.naij.com/fulani-herdsmenfrom-Libya-responsible-for-attacks-buhari.html

[29] Faul, M., Aikman, S. N., \& Sasser, S. M. (2016). Bystander intervention prior to the arrival of emergency medical services: Comparing assistance across types of medical emergencies. Prehospital Emergency Care, 1-7

[30] Godwin, A. C. (2018). Catholic Priests, 17 others killed by herdsmen for mass burial may 22 in Benue. Retrieved from: http://www.dailypost,ng/2018/05/15/catholic-priests-17others-killed-by herdsmen-for-mass-burial-may-22-inbenue/ on June 16

[31] Gyuse, T. F., \& Ajene, O. (Eds.) (2008). Conflicts in the Benue valley. Makurdi: Centre for Peace and Development Studies

[32] Hart, T. \& Miethe, T. (2008). Exploring bystander presence and intervention in nonfatal Violent victimization: When does helping really help? Violence and Victims, 23 (5), 637-651.

[33] Hudson, J. M. \& Bruckman, A. S. (2004). The bystander effect: A lens for understanding patterns of participation. Journal of the Learning Sciences, 13 (2), 165-195

[34] Igbo, E. U. M. (2007). Introduction to criminology. Nsukka: University of Internal Displacement

[35] Monitoring Centre (2015). Nigeria IDP figure analysis. Retrieved from http://www.internaldisplacement.org/IDM C\%displacement.org/IDMC\%20\%20\%Nigeria\%20IDP\%fi gures\%20Analysis.html?

[36] Igomu, J. (2016, May,10). Tension over cattlemen's unprovoked tyranny. Nigerian View, 3, 12-27

[37] Ihejwmaizu, E.C. (2002). Sociology of Nigeria rural people. Owerri: African Scholars Publishing Company.

[38] Ikoh, M.U. (2014). Policing, crime prevention and control in Nigeria. In R. Bassey, Alemika, E.E. \& O. Tangba. (Eds.). Policing and crime prevention in Nigeria. (pp.67-76), Jos: African Command on Narcotics and Crime Prevention

[39] Institute for Economic and Peace (2018). Global terrorism index 2018: Measuring and understanding the impact of terrorism. Sydney, Australia: IEP

[40] Iorhemen, C. (2018). Fulani herdsmen have killed over 1,500 farmers in 47 attacks" - Benue state government. Retrieved from: https://newtelegraphonline.com/2018/02/f ulani-herdsmen-killed-1500-farmers-47-attacks-benuestate-government/

[41] Iwarimie- Jaja, D. (2012). Criminology: The study of crime. 
Port Harcourt: Springfield Publishers

[42] Jones, L.M., Mitchal, K.J. \& Turner, H.A. (2015). Victim's reports of bystander reactions to in-person and online peer harassment: A national survey of adolescents. Journal of Youth and Adolescence. 4(2), 120-129

[43] Keeley, B.L. (1999). Of conspiracy theories. The Journal of philosophy, 96 (3), 109-126

[44] Latane, B. \& Dartey, J.M (1968). Group inhibition of bystander intervention and emergencies. Journal of Personality, 10 (3), 215-221.

[45] Mark, F. (2008). Conspiracy theories: Secrecy and power in American culture (2nd ed). University Minnesota: Minnesota University Press

[46] Michael, C.E., Chinwokwu, E.C \& Inyang, M.N. (2017). Residents' vulnerability to criminal victimization in Lafia, Nasarawa State. Online Journal of Arts, Management and Social Science, 2 (1), 127-139

[47] Michael, C.E., Ojedoku, U.A Chinwokwu, E.C (2013). Abolition of commercial motorbikes and its implication on transportation and criminality in Calabar metropolis. International Journal of Social Studies, 1 (1), 206-214

[48] Michael, C.E., Inyang, M.N \& Ukpong, M.J. (2017). Nonvulnerable against the vulnerable: A Socio-criminological analysis of herdsmen attack on vulnerable population in Nigeria. Online Journal of Arts, Management and Social Science, 2 (1), 89-102

[49] Michael, C. E. (2010). Public perception of the involvement of commercial motorcyclist in crime in Uyo Local Government Area, Akwa Ibom state. Unpublished M.Sc. dissertation, Department of Sociology, University of Ibadan, Ibadan

[50] Ndujihe, C., \& Ugochukwu, C. (2018). Violent death: 1,351 killed in 10 weeks. Retrieved from: http://www.vanguardn gr.com/2018/03/violent-death-1,351-killed-in-10-weeks/

[51] Nwankwo, B. O. (2015). Leading as fugitives: The case of militant groups in Nigeria's oil producing communities. American Journal of Educational Research, 3 (5), 599-603

[52] Obasaryo, O. (2002). Political thuggery and violence in Nigeria: the bane of women participation in polities. Retrieved from http://www.artilebase.com/politiesarticle/political-thurgery-and-violence-in-nigeria-the-bareobe/

[53] Odoh, S.I. \& Chigozie, C. F. (2012). Climate change and conflict in Nigeria: A theoretical and empirical examination of the worsening incidence of conflict between Fulani herdsmen and farmers in Northern Nigeria. Arabian Journal of Business Management Review, 2(1), 110-124.

[54] Okere, A. (2018). Soldiers kill vigilante, release arrested herdsmen in Edo. Retrieved from http://www.punchng.co $\mathrm{m}$ /soldiers-kill-vigilante-release-arrested-herdssmen-inedo/

[55] Okey, O. (2013). The Socio-economic implications of BookHaram activities in Northern Nigeria. Review of Public Administration and Management, 1 (2), 19-37

[56] Okolie, A. C., \& Ogayi, C. O. (2018). Herdsmen militancy and humanitarian crisis in Nigeria: A theoretical briefing.
African Security Review, 27(2), 129-143

[57] Okoli, A.C. \& Iortyer, P. (2014). Terrorism and humanitarian crisis in Nigeria from Boko Haram insurgency. Global Journal of Human Social Science, 4 (1), 39-50

[58] Okoli, A \& Atelhe, G.A. (2014) Nomads against Natives: A Political Ecology of Herder/Farmer Conflict in Nasarawa State, Nigeria. American International Journal of Contemporary Research, 4 (2), 76-88.

[59] Olayoku, P. (2014). Trends and patterns of cattle grazing and rural violence in Nigeria 2006-2014. Nigeria: IFRA

[60] Olmsted, K. S. (2011) Real enemies: Conspiracy theories and American democracy, World War I to 9/11. Oxford: Oxford University Press

[61] Okoye, P.S. (2015). Introduction to social problems: Concept and theories. Aba: Nfimitex Publishers

[62] Okpanga, A., Ugwu, S.C. \& Ene, O. (2012). Activities of Boko Haram and insecurity question in Nigeria. Arabian Journal of Business and Management Review, 1 (9), 77-98

[63] Peterson, S.G.B. (2015). Violence at a cross road. Lagos: Femi Press

[64] Sagarin, E \& Macnamara, D.E.J. (2012). Homosexual as a crime victim. International Journal of Criminology and Penology, 3, 13-25

[65] Sunstein, C.R. (2014). Conspiracy theories and other dangerous ideas. New York: Simon and Schuster.

[66] Sunsterin, C.R. \& Vermeute, A. (2009). Conspiracy theories: Causes and curse. Journal of Political Philosophy, 17 (2), 202-227

[67] Smith, G.O. (2013). Victimizing the vulnerable ethnic nationalities in Nigeria. Zaria: ABU Press

[68] Umar. Y. (2018). Yola court passes death sentence on five men for killing herdsman. Retrieved from: http://www.van guardngr.com/2018/06/yola-court-passes-death-sentenceon-five-men-for-killing-herdsman/ on June 15, 2018

[69] Wantu, J. (2015, May 15). Three die in Benue Fulani herdsmen attack. The Guardian, p. 13

[70] Wantu, J. (2016, April 26). Two hundred feared killed as herdsmen attack Benue. The Guardian, p.5

[71] World Population Review. (2019). Nigeria population 2019. Retrieved from http://worldpopulationreview.com/countrie s/nigeria-population/

[72] Wortley, R. (2010). Critique of situational crime prevention. In Fisher, B \& Lab, S (Eds). Encyclopedia of victimology and crime prevention (pp. 230-242), Thousand Oak: Sage

[73] Yusuf, O. (2016). We paid Fulani herdsmen to pacify them - Governor El-Rufai. Retrieved from https://www.naija.co $\mathrm{m} / 1071185$-we-paid-fulani-herdsmen-to-pacify-themgovernor-el-refui/ 